\title{
DIET AND SOCIO-ECONOMIC FACTORS AND THEIR ASSOCIATION WITH THE NUTRITIONAL STATUS OF PRE-SCHOOL CHILDREN IN A LOW INCOME SUBURB OF KAMPALA CITY, UGANDA
}

\author{
J.K. KIKAFUNDA and J.K. TUMWINE
}

\begin{abstract}
Objective: To establish dietary and socio-economic factors and their association with the nutritional status of pre-school children in a poor suburb of Kampala city, Uganda.

Design: A cross-sectional study.

Setting: Three nursery schools in a low income suburb of Kampala city, Uganda.

Subjects: A sub-sample of forty one randomly selected pre-school children (three to six years of age) from a larger intervention study, participated in the present investigation.

Results: The results reveal high levels of chronic malnutrition (stunting and underweight) among the children. Almost half (46.3\%) and one third (29.3\%) of the children had height-for-age and weight-for-age centiles, respectively, below the $20^{\text {th }}$ centile. The father's educational status was significantly $(p=0.017)$ associated with the children's nutritional status with all the children whose fathers had tertiary education and above having better weight-for-age centiles (above the $50^{\text {th }}$ ). Economic status too was significantly $(p=0.026)$ associated with the nutritional status of the children with children from the upper and mid-upper socio-economic classes having better weight-for-age centiles than children from the lower socio-economic status. Analysis of the diet showed a significant association between the nutrition status of the children and some of the foods consumed. Children who were above the $50^{\text {th }}$ weight-for-age centiles consumed significantly more bread $(p=0.008)$ and light-green-leafy vegetables $(p=0.020)$ than those who had lower weight-for-age centiles. Children who were above their $50^{\text {th }}$ height-for-age centiles consumed significantly $(p=0.049)$ more soybeans than children who had lower height-for-age centiles.

Conclusion: Socio-economic as well as dietary factors were found to be inextricably linked and have been shown to be significantly associated with the nutritional status in this group of suburban pre-school children in Kampala city, Uganda.
\end{abstract}

\section{INTRODUCTION}

The nutritional situation among children in developing countries, particularly those in sub-Saharan Africa, is sub-optimal with high rates of chronic malnutrition; stunting and underweight (1). In recent years, the proportions of underweight and stunted pre-school children have declined in all regions of the world except for parts of sub-Saharan Africa where the levels have remained the same and in some cases increased $(1,2)$. The effects of malnutrition are cumulative over the years and malnourished children enter adulthood with diminished mental and physical capacities. Chronic malnutrition is a very serious health and wellfare problem contributing to more than half of the child deaths world-wide (2). However, since its signs are not 
usually visible to the naked eye, chronic malnutrition is difficult to detect by the general public and has been appropriately termed the "silent emergency".

For a long time, Uganda had concentrated on fighting clinical malnutrition (kwashiorkor and marasmas) on the assumption that chronic malnutrition was not a big problem. However, the first Uganda Demographic and Health Survey (3) in the late 1980s revealed that chronic malnutrition was rampant in the country with almost half $(45 \%)$ of the children below five years of age being stunted (low height-for-age) and one quarter (25\%) underweight (low weight-for-age). By mid 1990s, the situation had not appreciably improved as $38 \%$ of children below five years of age were still stunted and $26 \%$ underweight (4). These results were confirmed by research work in one rural area of Central Uganda, which found high levels of stunting and underweight among children below five years of age (5). The nutritional status of Ugandan children is still of great concern as the recent nation-wide demographic and health survey found no positive change in the anthropometric indices of the children (6).

It is ironical that Ugandan children should be persistently plagued by malnutrition to this extent since the country enjoys a relatively stable food security situation and is considered by some as the "food basket" of the region. However, food security alone does not guarantee nutritional security as the causes of malnutrition are complex and multifactorial, ranging from inadequate dietary intake and health status to household food insecurity, inadequate care, insufficient health facilities, poor education, poverty, insecurity and many others.

There is limited information on factors contributing to childhood malnutrition especially in poor suburban areas of cities in Uganda. The purpose of this study was therefore to establish the dietary patterns and socio-economic factors and their association with the nutritional status of preschool children in a poor suburb of Kampala, the Capital city of Uganda.

\section{MATERIALS AND METHODS}

Subjects: The subjects of the study were pre-school children randomly selected from three nursery schools in Kawempe division, a suburb of Kampala city, Uganda. The children who attended the three schools came from households with varying socio- economic backgrounds. The majority of the children who attended School A came from families with higher socio-economic status while the majority of those who attended School B and C came from families with medium and low socio-economic status, respectively.

The paediatrician on the team carried out detailed clinical examinations. Children with medical problems such as heart disease, liver failure, obvious signs and symptoms suggestive of AIDS or physical disability, were excluded from the study but referred for further treatment at Mulago Hospital, Uganda's largest national referral hospital. From the 153 children who participated in the larger zinc supplementation study (7), a random sample of 41 children ( 21 boys and 20 girls) were randomly selected to participate in this nutrition assessment study. Fourteen children were from School A, 13 from School B and 14 from School C. The ages of the children ranged from three to six years.

Assessment of the nutritional status of the children: The nutritional status of the children were assessed using anthropometry (body measurements). Anthropometric measurements (weight and height) of the children were taken following international guidelines (9-11). Weight measurements were taken to the nearest $0.1 \mathrm{~kg}$ using a standardised Salter $25 \mathrm{Kg}$ Spring Scale (Salter Weight-Tronix Ltd., West Bromwich, West Midlands, UK). The standing height of the children was recorded to the nearest $0.1 \mathrm{~cm}$ using Short's Height measuring Board (short Productions, Woonsocket, Rhode Island, USA). The ages of the children were assessed from their birth records or consultations with their parents/guardians.

Quality control in taking the anthropometric measurements was ensured by the measurements being taken in triplicate and the average computed by taking the measurements at the same time of day (before the morning break time snacks) and the measurements being taken by the same person to avoid inter-personal variations.

The heights and weights of the children were used to compute the height-for-age and weight-forage centiles of the children. The median and standard deviation values in the WHO reference data (8) were manually used to classify children into three nutritional groupings: Group $1\left(<20^{\text {th }}\right.$ weightfor-age/height-for-age percentiles) representing the 
underweight/stunted children, Group $2\left(20^{\text {th }}-50^{\text {th }}\right.$ percentiles) representing the mildly underweight/ stunted children and Group 3 ( $>50^{\text {th }}$ percentiles) representing the well nourished children.

The questionnaire: A questionnaire was developed to collect data on the socio-demographic and socioeconomic background of the children. Background variables included the age of the mother, education and occupation of the mother and father and economic status of the households. The questionnaire was verified by the "jury" method (12). The homes of the children were visited and the mothers/caretakers of the children provided the information which the research assistants entered into the questionnaire.

Assessment of the diet of the Children: The assessment of diet of the children was carried out using three main methods; diet history, 24-hour food recalls and Food Frequency Questionnaire (FFQ). The diet history involved asking the mothers to name the foods that were commonly consumed in the household, in order of importance. These were broken down into the staple foods and the sauce/ relish that are usually consumed together with the staples. The 24 hour food recall involved asking the mother what the children ate the previous day, from the time the child woke up in the morning to the time he/she went to bed at night. The foods included both solid and liquid foods, main meals and snacks.

The FFQ had eight food frequency scores; 0 for the foods that were rarely or never consumed and one to seven for the number of days per week a particular food was usually consumed, i.e. one for once a week and seven for everyday. The FFQ was original having been specifically designed for this study so as to include local foods. The mothers/ caretakers of the children provided the information for both the 24 hour food recalls and FFQ.

Ethical Clearance: Ethical clearance was granted by the ethical committee of the Uganda National Council of Science and Technology. The study was explained to the parents and guardians of the children who gave written consent for their children to take part in the study.

Statistical analysis: The association of some common socio-demographic and socio-economic variables with the nutritional status of the children were assessed using bivariate analysis through cross tabulations. Significance was set at $p<0.05$. The relationships between the diet of the children and some selected variables were assessed using SAS's NPAR1WAY analysis of variance procedure. This is a non-parametric one-way analysis of rank scores that tests the distribution of a selected class variable between groups. The Kruskal-Wallis test of chisquare approximation was used to interpret significant differences in this analysis.

\section{RESULTS}

Background characteristics: The data on the background characteristics of the parents of the children such as age, education and occupation is given in Table l. The majority of the children (86.4\%) had mothers aged between 20 and 40 years. The proportion of young mothers ( $<20$ years) and old mothers (>40 years) was very low at $2.4 \%$ and $10.8 \%$, respectively. A large proportion of the children $(48.7 \%)$ had mothers with a secondary level education followed by those with a primary level education (33.3\%). A small proportion of the children $(4.9 \%)$ had mothers with no formal education but none of the children had a father without formal education. A large proportion of the children (48.7\%) had fathers with a secondary level education followed by those with tertiary level education $(15.4 \%)$. Most of the children (46.2\%) had mothers who were full time housewives while the majority of the fathers $(55.6 \%)$ were employed in the civil service. More than half of the children (53.7\%) were from households with a mid-lower economic status.

Nutritional status of the children: The percent distribution of the children in the various nutritional (anthropometric) groupings is shown in Table 2. 
Table 1

Percent (\%) distribution of the background characteristics of the parents of the children $(n=41)$

\begin{tabular}{|c|c|}
\hline Variable & (\%) Distribution \\
\hline \multicolumn{2}{|c|}{ Age of the mother (years) } \\
\hline$<20$ & 2.4 \\
\hline $20-40$ & 86.4 \\
\hline$>40$ & 10.8 \\
\hline \multicolumn{2}{|l|}{ Education of mother } \\
\hline None & 5.1 \\
\hline Primary & 33.3 \\
\hline Secondary & 48.7 \\
\hline High school & 4.9 \\
\hline Tertiary & 7.7 \\
\hline \multicolumn{2}{|l|}{ Education of father } \\
\hline None & 0.0 \\
\hline Primary & 10.3 \\
\hline Secondary & 48.7 \\
\hline High school & 15.4 \\
\hline Tertiary & 25.6 \\
\hline \multicolumn{2}{|c|}{ Occupation of the mother } \\
\hline Housewife & 46.2 \\
\hline Civil servant & 30.8 \\
\hline Trader/business & 23.0 \\
\hline \multicolumn{2}{|l|}{ Occupation of the father } \\
\hline Civil servants & 55.6 \\
\hline Peasant farmer & 0.0 \\
\hline Trader/business & 19.5 \\
\hline Other & 24.6 \\
\hline \multicolumn{2}{|l|}{ Economic status } \\
\hline Upper & 7.3 \\
\hline Mid-upper & 24.4 \\
\hline Mid-lower & 53.7 \\
\hline Low & 14.6 \\
\hline
\end{tabular}

Almost one third of the children (29.3\%) were underweight i.e. having a weight-for-age below the $20^{\text {th }}$ percentile while almost half of the children $(46.3 \%)$ were stunted i.e. having height-for-age below the $20^{\text {th }}$ percentile. The mildly underweight/ stunted children comprised $43.9 \%$ and $24.4 \%$, respectively while slightly over one quarter of the children were well nourished with weight-for-age (26.8\%) and height-for-age (29.3\%) above the 50th percentiles.

The diet of the children: The staple foods commonly consumed in the children's households, in order of importance as reported by the mothers/caretakers, are shown in Table 3. The East African green cooking banana locally known as matooke was the most important staple in the diet of the children as more than one half of the household (53.7\%) named it as their number one staple food. This was followed by rice $(29.3 \%)$ and maize $(12.2 \%)$. Table 3 also shows the sauces (relish) which usually accompany the staple foods. The common bean (Phaseolus vulgaris) was the most important relish as the majority of mothers/caretakers (36.6\%) named it as their number one sauce followed by ground-nuts (19.5\%), fish (19.5\%) and meat (12.2\%).

The 24-hour food recall revealed that 23 foods had been consumed by the children the day preceding the interview. These foods included staple foods such as matooke, sweet potatoes, cassava, rice, maize meal, millet meal, bread and potatoes; relishes such as beans, peas, green vegetables, meat, eggs, fish and ground nuts; beverages such as milk tea, dry tea and maize porridge; assorted fruits such as passion fruit and citrus fruits and; condiments such as margarine. The percent distribution of the

Table 2

Percent $(\%)$ distribution of the nutritional status of the children $(n=41)$

\begin{tabular}{|c|c|c|c|c|c|}
\hline Variable & Groupings & Nutritional status & $\%$ Distribution & Proportion & CI $(95 \%)$ \\
\hline \multicolumn{6}{|c|}{ Weight-for-age centiles } \\
\hline$<20^{\text {th }}$ Centile & Group 1 & Underweight & 29.3 & 0.293 & $0.154,0.432$ \\
\hline 20-50 ${ }^{\text {th }}$ Centile & Group 2 & Mildly underweight & 43.9 & 0.439 & $0.287,0.591$ \\
\hline$>50^{\text {th }}$ Centile & Group 3 & Well-nourished & 26.8 & 0.268 & $0.132,0.403$ \\
\hline \multicolumn{6}{|c|}{ Height-for-age centiles } \\
\hline$<20^{\text {th }}$ Centile & Group 1 & Stunted & 46.3 & 0.463 & $0.311,0.615$ \\
\hline 20-50 $0^{\text {th }}$ Centile & Group 2 & Mildly stunted & 24.4 & 0.244 & $0.108,0.375$ \\
\hline$>50^{\text {th }}$ Centile & Group 3 & Well-nourished & 29.3 & 0.293 & $0.154,0.432$ \\
\hline
\end{tabular}


proportion of children who consumed a certain food the day preceding the interview is shown in Figure 1. A large majority of the children $(89.0 \%)$ were reported to have consumed bread followed by matooke $(65 \%)$, milk tea $(42 \%)$, beans $(41 \%)$, meat $(38 \%)$ and others as shown in Figure 1.
Association between socio-demographic background and the nutritional status of the children: The nutritional status of the children i.e. whether below the 20th weight-for-age/height-for-age centile (Group 1), $20^{\text {th }}-50^{\text {th }}$ weight-for-age/height-for-age centile (Group 2) and above $50^{\text {th }}$ weight-for-age/height-for-

Table 3

Percent (\%) distribution of the households against foods usually consumed in order of importance of the foods $(n=41)$

\begin{tabular}{lrrrr}
\hline Food & $1^{\text {st }}$ & $2^{\text {nd }}$ & $3^{\text {rd }}$ & $4^{\text {th }}$ \\
\hline Staple foods & & & & \\
$\quad$ Matooke & 53.7 & 14.6 & 14.6 & 2.4 \\
Rice & 29.3 & 24.4 & 24.4 & 12.2 \\
Maize & 12.2 & 31.7 & 17.1 & 14.6 \\
Sweet potatoes & 2.4 & 14.6 & 22.0 & 39.0 \\
Cassava & 2.4 & 7.3 & 4.9 & 17.1 \\
Irish potatoes & 0.0 & 7.3 & 17.1 & 9.8 \\
Sauce (Relish) & & & & \\
Beans & 36.6 & 22.0 & 17.1 & 7.3 \\
Ground nuts & 19.5 & 22.0 & 26.8 & 9.8 \\
Fish & 19.5 & 29.3 & 26.8 & 12.2 \\
Meat & 12.2 & 22.0 & 17.1 & 19.5 \\
Vegetables & 2.4 & 5.1 & 9.8 & 31.7 \\
Peas & 2.4 & 4.9 & 2.4 & 7.3 \\
\hline
\end{tabular}

Figure 1

Percent (\%) distribution of children by food consumed 24 hours before the interview (The 24-hour food recall)

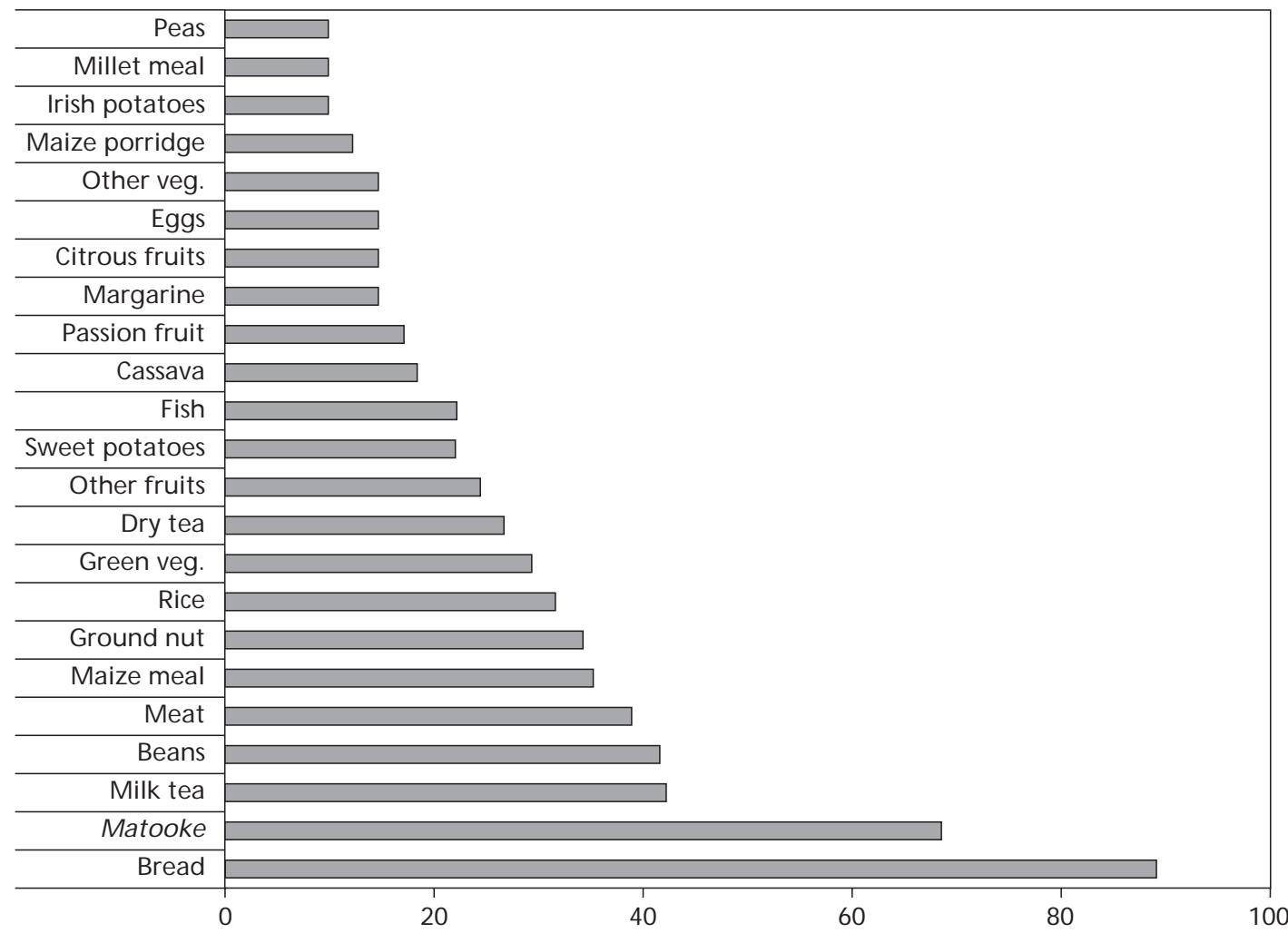


age centile (Group 3) were examined at bivariate level in cross tabulations with some common sociodemographic background variables such as age, education and occupation of the parents and socioeconomic status of the household. This was to assess the factors that were more likely to be associated with the nutritional status of the children. Neither the age nor education of the mother had a significant association with nutritional status of the children for both weight-for-age and height-for-age. The education of the father, however, had a significant $(\mathrm{p}=0.017)$ association with the weight-for-age centile with children whose fathers had lower than tertiary level education having low weight-for-age centiles $\left(<50^{\text {th }}\right)$.

The occupation of the mother and that of the father had no significant association with the nutritional status of the children, in this study. The economic status of the households, however, had a significant $(p=0.026)$ association with the weightfor-age status of the children. All the children whose household were in the upper and mid-upper socioeconomic class had weights over the $50^{\text {th }}$ centiles. However, the economic status of the families had no statistically significant association with the height-for-age status of the children, in this study.
Association between diet and the nutritional status of the children: Using the three nutritional groupings explained above and the results of the food frequency questionnaire, the association between diet and the nutritional status of the children was assessed using SAS's NPAR1WAY analysis of variance. This is a non-parametric one-way analysis of rank scores that tests the distribution of a selected class variable between groups. The class variable in this case is the nutritional status of the children. The average number of times per week a particular food was consumed by members of a group was computed as a Food Frequency (FF) mean score. The maximum FF mean square a group could have was seven, meaning that all the children in that group consumed that particular food everyday of the week. The analysis then tested whether there was a significant association between the number of times a week a particular food was consumed by the group and that groups' nutritional status. The results are shown in Table 4 for weight-for-age and Table 5 for height-for-age. There were some significant associations in the frequency of consumption of a few foods and the nutritional status of the groups.

Table 4

Relationship between the diet of the children and their nutritional status (Weight-for-age)

\begin{tabular}{|c|c|c|c|c|c|}
\hline Food & $\begin{array}{l}\text { Class variable } \\
\left({ }^{4} \text { Groupings }\right)\end{array}$ & $\begin{array}{c}{ }^{1} \text { FF Mean } \\
\text { Score }\end{array}$ & $\begin{array}{c}{ }^{2} \text { Among } \\
\text { MS }\end{array}$ & $\begin{array}{c}{ }^{3} \text { Within } \\
\text { MS }\end{array}$ & P-value \\
\hline Maize & $\begin{array}{l}\text { Group } 3 \\
\text { Group } 2 \\
\text { Group } 1\end{array}$ & $\begin{array}{l}1.82 \\
2.89 \\
3.33\end{array}$ & 6.98 & 4.27 & 0.370 \\
\hline Rice & $\begin{array}{l}\text { Group } 3 \\
\text { Group } 2 \\
\text { Group } 1\end{array}$ & $\begin{array}{l}2.91 \\
2.61 \\
2.83\end{array}$ & 0.35 & 3.81 & 0.826 \\
\hline Bread & $\begin{array}{l}\text { Group } 3 \\
\text { Group } 2 \\
\text { Group } 1\end{array}$ & $\begin{array}{l}7.00 \\
6.06 \\
4.50\end{array}$ & 18.59 & 3.79 & 0.008 \\
\hline Sweet potatoes & $\begin{array}{l}\text { Group } 3 \\
\text { Group } 2 \\
\text { Group } 1\end{array}$ & $\begin{array}{l}1.73 \\
1.89 \\
1.50\end{array}$ & 0.54 & 3.18 & 0.516 \\
\hline Matooke & $\begin{array}{l}\text { Group } 3 \\
\text { Group } 2 \\
\text { Group } 1\end{array}$ & $\begin{array}{l}5.09 \\
4.83 \\
4.33\end{array}$ & 1.74 & 5.69 & 0.768 \\
\hline
\end{tabular}


Table 4 (continued)

\begin{tabular}{|c|c|c|c|c|c|}
\hline Food & $\begin{array}{l}\text { Class variable } \\
\left({ }^{4} \text { Groupings }\right)\end{array}$ & $\begin{array}{l}{ }^{1} \text { FF Mean } \\
\text { Score }\end{array}$ & $\begin{array}{c}{ }^{2} \text { Among } \\
\text { MS }\end{array}$ & $\begin{array}{c}{ }^{3} \text { Within } \\
\text { MS }\end{array}$ & P-value \\
\hline \multirow[t]{3}{*}{ Beans } & Group 3 & 2.64 & \multirow[t]{3}{*}{1.60} & \multirow[t]{3}{*}{4.80} & \multirow[t]{3}{*}{0.777} \\
\hline & Group 2 & 3.28 & & & \\
\hline & Group 1 & 3.25 & & & \\
\hline \multirow[t]{3}{*}{ Groundnuts } & Group 3 & 3.36 & \multirow[t]{3}{*}{1.41} & \multirow[t]{3}{*}{4.79} & \multirow[t]{3}{*}{0.726} \\
\hline & Group 2 & 2.72 & & & \\
\hline & Group 1 & 3.00 & & & \\
\hline \multirow[t]{3}{*}{ Soybean } & Group 3 & 1.00 & \multirow[t]{3}{*}{0.17} & \multirow[t]{3}{*}{5.81} & \multirow[t]{3}{*}{0.488} \\
\hline & Group 2 & 1.22 & & & \\
\hline & Group 1 & 1.67 & & & \\
\hline \multirow{3}{*}{$\begin{array}{l}\text { Meat } \\
\text { (all types) }\end{array}$} & Group 3 & 3.09 & \multirow[t]{3}{*}{3.44} & \multirow[t]{3}{*}{3.92} & \multirow[t]{3}{*}{0.445} \\
\hline & Group 2 & 2.17 & & & \\
\hline & Group 1 & 2.17 & & & \\
\hline \multirow[t]{3}{*}{ Fish } & Group 3 & 3.00 & \multirow[t]{3}{*}{0.90} & \multirow[t]{3}{*}{3.35} & \multirow[t]{3}{*}{0.694} \\
\hline & Group 2 & 2.50 & & & \\
\hline & Group 1 & 2.58 & & & \\
\hline
\end{tabular}

${ }^{1} \mathrm{FF}$ (Food Frequency) Scores - 0 (rarely or never eaten); 1-7 (once to seven times a week);

${ }^{2}$ Among Mean Square = Effect Mean Square;

${ }^{3}$ Within Mean Square $=$ Error Mean Square; 4 Group $3(>50$ th $)$, Group $2\left(20-50^{\text {th }}\right)$ Group $1\left(<20^{\text {th }}\right)$

Table 5

Relationship between the diet of the children and their nutritional status (Height-for-age)

\begin{tabular}{|c|c|c|c|c|c|}
\hline Food & $\begin{array}{l}\text { Class variable } \\
\text { ( }{ }^{4} \text { Groupings) }\end{array}$ & $\begin{array}{c}\text { FF Mean } \\
\text { Score }\end{array}$ & $\begin{array}{c}\text { Among } \\
\text { MS }\end{array}$ & $\begin{array}{l}\text { Within } \\
\text { MS }\end{array}$ & P-value \\
\hline Maize & $\begin{array}{l}\text { Group } 3 \\
\text { Group } 2 \\
\text { Group } 1\end{array}$ & $\begin{array}{l}2.08 \\
3.90 \\
2.53\end{array}$ & 9.75 & 4.12 & 0.147 \\
\hline Rice & $\begin{array}{l}\text { Group } 3 \\
\text { Group } 2 \\
\text { Group } 1\end{array}$ & $\begin{array}{l}2.92 \\
2.40 \\
2.84\end{array}$ & 0.86 & 3.79 & 0.697 \\
\hline Bread & $\begin{array}{l}\text { Group } 3 \\
\text { Group } 2 \\
\text { Group } 1\end{array}$ & $\begin{array}{l}5.92 \\
6.70 \\
5.37\end{array}$ & 5.84 & 4.46 & 0.260 \\
\hline Sweet potatoes & $\begin{array}{l}\text { Group } 3 \\
\text { Group } 2 \\
\text { Group } 1\end{array}$ & $\begin{array}{l}1.92 \\
1.70 \\
1.63\end{array}$ & 0.31 & 3.20 & 0.740 \\
\hline Matooke & $\begin{array}{l}\text { Group } 3 \\
\text { Group } 2 \\
\text { Group } 1\end{array}$ & $\begin{array}{l}4.50 \\
4.90 \\
4.84\end{array}$ & 0.57 & 5.75 & 0.884 \\
\hline Beans & $\begin{array}{l}\text { Group } 3 \\
\text { Group } 2 \\
\text { Group } 1\end{array}$ & $\begin{array}{l}3.50 \\
3.00 \\
2.89\end{array}$ & 1.41 & 4.81 & 0.730 \\
\hline
\end{tabular}


Table 5 (continued)

\begin{tabular}{|c|c|c|c|c|c|}
\hline Food & $\begin{array}{l}\text { Class variable } \\
\left({ }^{4} \text { Groupings }\right)\end{array}$ & $\begin{array}{c}{ }^{1} \text { FF Mean } \\
\text { Score }\end{array}$ & $\begin{array}{c}{ }^{2} \text { Among } \\
\text { MS }\end{array}$ & $\begin{array}{c}{ }^{3} \text { Within } \\
\text { MS }\end{array}$ & P-value \\
\hline Groundnut & $\begin{array}{l}\text { Group } 3 \\
\text { Group } 2 \\
\text { Group } 1\end{array}$ & $\begin{array}{l}2.92 \\
2.20 \\
3.42\end{array}$ & 4.91 & 4.61 & 0.300 \\
\hline Soybean & $\begin{array}{l}\text { Group } 3 \\
\text { Group } 2 \\
\text { Group } 1\end{array}$ & $\begin{array}{l}2.42 \\
0.90 \\
0.47\end{array}$ & 14.28 & 5.07 & 0.049 \\
\hline Meat (all types) & $\begin{array}{l}\text { Group } 3 \\
\text { Group } 2 \\
\text { Group } 1\end{array}$ & $\begin{array}{l}2.58 \\
3.00 \\
2.00\end{array}$ & 3.52 & 3.92 & 0.433 \\
\hline Fish & $\begin{array}{l}\text { Group } 3 \\
\text { Group } 2 \\
\text { Group } 1\end{array}$ & $\begin{array}{l}2.17 \\
3.00 \\
2.79\end{array}$ & 2.20 & 3.28 & 0.674 \\
\hline
\end{tabular}

${ }^{1} \mathrm{FF}$ (Food Frequency) Scores - 0 (rarely or never eaten); 1-7 (once to seven times a week);

${ }^{2}$ Among Mean Square = Effect Mean Square;

${ }^{3}$ Within Mean Square = Error Mean Square;

${ }^{4}$ Group $3\left(>50^{\text {th }}\right)$, Group $2\left(20-50^{\text {th }}\right)$, Group $1\left(<20^{\text {th }}\right)$

The frequency of consumption for bread by children who were above the $50^{\text {th }}$ weight-for-age centiles (Group 3) was significantly $(p=0.008)$ higher than for the children who were below their $50^{\text {th }}$ weight-for-age percentiles. The FF mean score for Group 3 for bread was 7.00, followed by 6.06 for Group 2 and 4.50 for Group 1.

The frequency of consumption for soybean by children who were above the $50^{\text {th }}$ height-for-age centiles (Group 3) was significantly ( $p=0.049)$ higher than for the children who were below their $50^{\text {th }}$ height-for-age percentiles. Soybean had a FF mean score of 2.56 for Group 3, 0.90 for Group 2 and 0.4 for Group 1 .

Relationship between the diet of the children and their socioeconomic background: The NPAR1WAY analysis of variance was repeated using economic status of the families as the class variable. It was found that the frequency of consumption of pork were significantly $(p=0.01)$ higher for the children from families with relatively higher socio-economic status than those with a medium and low socio-economic status.

Since the majority of the children attending the different schools had varying socio-economic backgrounds, the differences between the frequencies of consumption of foods by the children in the different schools were also investigated. The frequency of consumption of bread and tea by children in the school with the relatively high socio-economic class (School A) was significantly $(p=0.0001)$ higher than that of children from the school with medium (School B) and low (School C) socio-economic status. In fact, all the children from this school consumed bread and tea every day: a food frequency mean score of 7.00. Children in this school also consumed margarine at significantly $(p=0.041)$ higher frequency than the other schools. The children from School A also consumed beef at a significantly $(p=0.0001)$ higher frequency than the other schools. The FF mean score for beef was 4.30 compared to FF mean scores of 2.57 and 1.18 for School B and C, respectively.

The frequency of consumption of vegetables was significantly $(p=0.019)$ higher for children from School $C$ with a FF mean score of 3.35 compared to FF mean scores of 2.43 and 1.30 for School B and A, respectively. The frequency of consumption of passion fruit was also significantly $(\mathrm{p}=0.019)$ higher in School $\mathrm{C}$ with a FF mean score of 5.29 compared to FF mean scores of 2.90 and 2.79 for School A and B, respectively.

\section{DISCUSSION}

In this study, the dietary patterns and the socioeconomic factors were determined and their 
association with the nutrition status of children in a suburban area in Kampala, the capital city of Uganda, was explored. It was found that the education of the father had a significant $(p=0.017)$ association with the children's nutritional status as all the children whose fathers had tertiary level education and above had weight-for-age centiles above $50^{\text {th }}$. These findings are in agreement with those from the Uganda Demographic and Health Surveys $(3,4,6)$ and by several other workers in Uganda (13-15), who established that the level of the father's education was an important determinant of the child's nutritional status. This could be partly explained by the fact that the educational status of the father is inextricably linked to the economic status of the household.

The finding that the mothers' education level had no relationship with the child's nutritional status is surprising but not unexpected in studies with urban settings as other workers in Uganda (13), Zimbabwe (16) and Nigeria (17) have had similar findings. Nonetheless, education of the mother is important in children's welfare as evidenced by several studies. Our previous work in a rural setting in Central Uganda (5) with younger children (<30 months) found a significant and positive association between the level of education of the mother and the health and nutritional status of the children. Other researchers from Uganda $(13,18)$ and Ghana $(19)$ have also noted an important association between the mothers' education on the child's nutrition status.

Education of the parents exerts its impact on the nutritional status of the children through improvement of economic status, improved health knowledge, health facility utilisation, readiness to accept new ideas, improved child care skills and greater involvement of the parents in decisions regarding health care $(15,20,21)$.

The main diet of the children was dominated by bread, the green cooking banana (matooke) and beans. Matooke and beans had been found to be the main diet of younger children (<30 months) in our earlier study in a rural district in Central Uganda (22). It is noteworthy that vegetables which are rich sources of micronutrients, were consumed by a negligible proportion of the children. This could be one of the contributing factors for the high levels of micronutrient malnutrition among children in Uganda (6). The larger micronutrient study to which this was a sub-set (7) had concluded that response to micronutrient supplementation may depend on adequate intake of other micronutrients, such as might be obtained from a varied diet.

A relationship between specific foods and the nutritional status of children has not been documented before in Uganda. Although there were no major associations between the foods regularly consumed by the children and their nutritional status, some few notable foods did show positive relationships. Consumption of bread ( $p=0.008)$ and light green vegetables $(p=0.020)$ were positively associated with higher weight-for-age centiles. Soybean was positively ( $p=0.049$ ) associated with better height-for-age centiles. Workers in Canada (23) established that children with low height-for-age centiles consumed significantly ( $p=0.01)$ less meat, fish and poultry than the children who had normal growth centiles.

Higher socio-economic status was found to be significantly $(p=0.026)$ associated with better nutritional status of the children as more children from the upper and mid-upper socio-economic classes had weight-for-age centiles above $50^{\text {th }}$. Children from the school with relatively higher socioeconomic status also had better anthropometric indices. These results are in agreement with our previous studies $(5,13)$ and studies elsewhere $(15,24)$ where higher socio-economic status was associated with better nutritional status.

\section{CONCLUSION}

Although the fathers' educational status, and not the mothers', had a significant association with the nutritional status of the children, this has to be weighted in the context of the economic status of the households. In addition, more research is needed using a larger sample size. Nonetheless, there is need to involve fathers in community nutrition improvement programmes, and not focus on mothers alone, as has been the practice. Both socio-economic and dietary factors were found to be inextricably linked and have been shown to be important determinants of nutritional status in this group of suburban pre-school children in Kampala city, Uganda.

\section{ACKNOWLEDGEMENTS}

This study was sponsored by the World Bank through Uganda's National Agricultural Research 
Organisation (NARO) to which we are highly indebted. Great appreciation also goes to Dr. Ann F. Walker of The University of Reading, UK, for her invaluable advice.

\section{REFERENCES}

1. James P., Norum K.R., Smitasiri S., et al. Ending malnutrition by 2020: An agenda for change in the millenium. ACC/SCN, WHO, Switzerland, Geneva. 2000.

2. UNICEF (United Nations Children's Fund). The state of the World's children: Focus on nutrition. Oxford University Press. 1998.

3. UDHS (Uganda Demographic and Health Survey). 1988/89. Ministry of Health (Uganda) and Demographic and Health Surveys, Institute for Resource Development/Macro Systems inc., Columbia Maryland, USA. 1989.

4. UDHS (Uganda Demographic and Health Survey). Nutrition and Health Status of young children and their mothers in Uganda; Findings from the 1995 Uganda Demographic and Health survey. Macro International/USAID/IMPACT. 1996.

5. Kikafunda J.K., Walker A.F., Collet D. and Tumwine J.K. Risk factors for early childhood malnutrition in Uganda (Electronic article). Paediatr. 1998; 102: e45-e54.

6. UDHS (Uganda Demographic and Health Survey), 2000-2001. Uganda Bureau of Statistics and ORC Macro, Calverton, Maryland, USA. 2001

7. Kikafunda J.K., Walker A.F., Allan E.F. and Tumwine J.K. Effect of zinc supplementation on growth and body composition of Ugandan preschool children: a randomised, controlled, intervention trial. Amer. J. Clin. Nutr. 1998; 68: 1261-1266.

8. WHO. Measuring changes in nutritional status. Annex 3. Reference data for weight and height of children. WHO, Geneva, Switzerland. 1983.

9. Cameron, M. and Hofvander, Y. Manual on feeding infants and young children. $3^{\text {rd }}$ ed. Oxford, England. Oxford University Press. 1983.

10. United Nations. National Household Survey Capability Programme, "How to weigh and measure children: Assessing the nutritional status of young children in house-hold surveys." United Nations Department of Technical Cooperation for Development and Statistical Office, New York. 1986.

11. FAO, conducting small-scale nutrition surveys: a field manual. Nutrition Planning, Assessment and Evaluation Services. Food Policy and Nutrition Division, FAO. 1990.
12. Uweagbute A.C. Weaning practices and weaning foods of the Hausas, Yorubas and Ibos of Nigeria. Ecol. Food Nutr. 1991; 26: 139-153.

13. Owor M., Tumwine J.K. and Kikafunda J.K. Socioeconomic risk factors for severe protein energy malnutrition among children in Mulago Hospital, Uganda. East Afr. Med. J. 2000; 77: 471-475.

14. Jitta J., Migadde M. and Mudusu J. Determinants of malnutrition in the under fives in Uganda: An in depth secondary analysis of the UDHS 1988/9 data. Uganda Ministry of Health and Child Health and Development Centre, Makerere University. 1992.

15. Vella V., Tomkins A., Borghesi A., et al. Determinants of child nutrition and mortality in North West Uganda. Bull. World Health Org. 1992; 70: 637-643.

16. Nhembe M. and Waterston T. Causes of malnutrition in Harare Hospital: a case controlled study. Central Afr. J. Med. 1984; 30: 97-101.

17. Oyedeji G.A., Olamijulo S.K. and Osinaike A.I. Secular trends in growth of children aged 0-6 years in a rural Nigerian community. Annals Trop. Paediat. 1996; 16: 1117.

18. Vella V., Tomkins A., Borghesi A., Migliori G.B. and Oryem V.Y. Determinants of stunting and recovery from stunting in Northwest Uganda. Int. J. Epidemiol. 1994; 23: 782-786.

19. Rikimaru T., Yartey J.E., Taniguchi K., Kennedy D.O. and Nkrumah F.K. Risk factors for the prevalence of malnutrition among urban children in Ghana. J. Nutr. Sci. Vitamino (Tokyo). 1998; 44: 391-407.

20. Goodburn J.G. and Senapati S. Strategies educated mothers use to ensure health of their children. J. Trop. Paediat. 1990; 36: 17-23.

21. Radebe B.Z., Brady J.P., Siziya S. and Todd H. Maternal risk factors for childhood malnutrition in Mazowe district of Zimbabwe. Central Afr. J. Med. 1996; 42: 240-249.

22. Kikafunda J.K., Walker A.F. and Tumwine J.K. Weaning foods and practices in Uganda: A crosssectional study. Afr. J. Food, Agric. Nutr. Develop. 2003; 3: Electronic article; http://www.ajfand.net

23. Smit-Vanderkooy P.D. and Gibson R.S. Food consumption patterns of Canadian pre-school children in relation to zinc status. Amer. J. Clin. Nutr. 1987; 45: 609-616.

24. El-Sayed N., Mohammed A.G., Nofal L., Mahfouz A. and Zeid H.A. Malnutrition among pre-school children in Alexandria, Egypt. J. Health Popul. Nutr. 2001; 19: 275-280. 